\title{
Educational networks: a key driving force for school development in a time of crisis and change
}

\author{
Joe O'Hara ${ }^{1 *}$, Patrick Shevlin ${ }^{1}$, Martin Brown ${ }^{1}$, and Gerry McNamara ${ }^{1}$ \\ ${ }^{1}$ Dublin City University, Institute of Education, Centre for Evaluation, Quality and Inspection, \\ Dublin, Ireland
}

\begin{abstract}
This paper examines the rise of networking in education, paying particular attention to the recent recognition of their importance during the unprecedented challenges that have emerged for schools during the COVID-19 period. The paper begins with an overview of the development of network theory, exploring how the concept has been adopted across a series of disciplines as a mode of organisational and personal development. It is evidentiated that networks are goal driven, rely on good communication, are challenging and seek to provide a way for school communities to uncover and transmit the knowledge that helps them ensure effective teaching and learning. The paper subsequently examines how networking has been adapted for educational settings and has become increasingly seen as a potential answer to many of the challenges facing rapidly changing social and educational contexts. Most notably, networking has a significant impact in the field of organisational leadership. The understanding of leadership as a mode that sees power and authority distributed among school communities as a whole has at its heart an awareness of the necessity to network, communicate and dialogue within schools and, perhaps as importantly, between schools. The paper concludes with a brief introduction to the emerging discourse surrounding the potential of networks to re-imaging educational provision in a Covid19 context.
\end{abstract}

Keywords: educational networks, public policy, teaching and learning, covid-19.

\section{Introduction: the rise of networks}

The importance of networks to the enhancement of organisational capacity is a concept that has been widely recognised across the public and private sector [1]. Indeed in the public and non-profit sector, collaboration is no longer simply an option; it has become the new orthodoxy with Hertting and Vedung suggesting that "evaluation and network governance are both among the top 10 trendy concepts in public policy" [2, p. 29]. It is arguable that one of the reasons networking has become so popular as a guiding principle of organisational development is its definitional malleability. Chapman and Hadfield, for

* Corresponding author: joe.ohara@dcu.ie 
example, argue that "the sheer plasticity of the term network means that it has been applied to a wide range of social and technological phenomena" [3, p. 310]. Azorin drawing on the work of Van Dijk (2006) goes so far as to argue that "networks are fast becoming the nervous system of our society and it is no exaggeration to state that the twenty-first century is the age of networks" [4, p. 105].

\section{Methods}

This paper applied the method of literature review that allowed to define the conceptual foundations for sustainable networking, explain the role of networks for organisational development in the field of education. We provide an overview of the recent theories on networking that conceptualize it from various dimensions: as a new form of public governance, as a new type of leadership, as well as from the point of view of their efficacy and impact.

\section{Results: educational networks}

As with all innovative theories brought into educational practice, it is important to understand the conceptual foundations underpinning the idea of networks. Scholars of network theory suggest that due consideration must be given to the guiding principles that undergird efficient and sustainable networks, such as "network goal consensus" [5], "purpose and identity" [3, 5], "reciprocity" [6], "equity" [7] and "trust" [8]. Daly and Finnigan [9] describe conditions for successful educational networks identified in the National College for School Leadership's Network Learning project [10]. They suggest that the key conditions of these successful networks included frequent and pervasive communication, shared understanding and purpose, collaborative challenging work, and relationships built on trust that enabled the transfer of tacit and explicit knowledge $[9, \mathrm{p}$. 114]. Thus networks are goal driven, rely on good communication, are challenging and seek to provide a way for school communities to uncover and transmit the knowledge that helps them ensure effective teaching and learning.

It is interesting to note that while the idea of the centrality of networks to organisational development is prevalent in other disciplinary areas, it is comparatively new in education [11]. Commenting on this in 2010 Muijs et al. suggested that, "while networking has only recently come to the fore in education, the concept is long established in different fields, with strong roots in psychology, social science, and business studies..." [12, p. 6]. DiazGibson et al. in reference to Daly and Finnigan [9] also noted that "the idea of networks in support of educational improvement, while still in its infancy, is gaining momentum in education" $[13$, p. 180]. This momentum is perhaps understandable given the emergence of a body of evidence pointing to the benefits of being part of an educational network that emerged in the second decade of the 21 st century. The identified positives of networks include improved learning, the efficient use of resources, heightened innovation capacity and system-wide improvement $[3,14,15,16]$. As a result, educational networks and, in particular, formalised educational networks began to emerge in countries throughout Europe.

Many of the ideas underpinning the development of these networks are consistent with influential theories known collectively as "new public governance" [17]. Indeed a substantial number of education networks have emerged in countries throughout Europe and beyond [14]. To take the example of Netherlands in the first instance, special and mainstream schools established networks with a view to allowing them to work together to provide an inclusive education [18]. In the region of Barcelona in Spain networks were 
established with a view to reducing student absenteeism [19]. In South America, Chilean school improvement networks were established throughout the country to facilitate school principals and administrators to share best practice and strategies for improvement [20]. Other studies identify similar developments across a broad range of education systems highlighting the role of networks in facilitating the establishment of new ways of working in order to improve the quality of educational provision across the entire continuum [21].

Perhaps naturally the drive to establish networks has seen the emergence of a parallel critique of their efficacy and impact. Much attention has been paid to the quality of outcomes derived from network participation initiative with the argument being put forward that there is a significant differential depending on the nature, context, structure and operation of the network. Prenger, Poortman, \& Handelzalts in their analysis of education networks in the Netherlands found that there were only "moderately positive effects on teachers" perceived satisfaction; the knowledge, skills, and attitude developed; and their application to practice" [16, p. 1]. Sammons, Mujtaba, Earl, \& Gu undertook an analysis of the English Network Learning Communities (NLC) initiative and argued that "while some schools and networks have shown marked improvement across a range of outcomes, the findings indicated that there is no overall NLC effect on attainment outcomes; rather, there is considerable variation at the school level within and between networks" [22, p. 213].

Notwithstanding the somewhat equivocal evidence that emerged with regards to network operation, there has been an increased prioritisation of their utility in a number of discrete fields of educational research. Perhaps the most important of these has been in the field of leadership studies. As an area, leadership studies has been undergoing a significant "paradigm shift" moving away in many cases from the idea of leadership being invested in one particular individual to one which sees leadership as being "distributed" across an organisation [23]. Championed by writers such as Spillane, Harris and Jones [24], Harris [25], Harris and De Flaminis [26], and Azorin [4] this view of leadership has become normative in the course of the last few years. Arguing for a mode of leadership that sees power and authority distributed among school communities as a whole, this understanding has at its heart an awareness of the necessity to network, communicate and dialogue within schools and, perhaps as importantly, between schools. Indeed Azorin, Harris and Jones [27, p. 111] argue that "leaders at all levels are being challenged to collaborate and network in order to secure the best positive outcomes for students".

\section{Discussion: educational networks and Covid-19}

The past decade has seen a steady growth in the acceptance of the importance of educational networks across a number of discrete disciplinary fields. Whilst acknowledging this, it is unarguable that the first 9 months of 2020 have resulted in a step-change in their adoption and adaptation. Azorin, Harris, and Jones [27, p. 246], reflecting on the impact of the Covid-19 pandemic on school leaders argued that they are now required to "connect, share, learn and network their way through issues". At a fundamental level, many schools have been required to rapidly reorient their mode of teaching to one that relies on technology in a manner that would have appeared impossible 12 months ago [28]. This recalibration has seen a culture of learning emerge in many schools that is lateral, technology enhanced and prioritises the sharing and creation of knowledge across school communities at every level. It has also seen an increased permeability of school boundaries with a requirement to engage and network with different stakeholding groups in meaningful and potentially transformational ways. Thus ideas such as parental and student voice in education have moved from a relatively peripheral position to the centre of discussions about how a transformed educational landscape can ensure that teaching and learning remain maximally effective [29]. At the heart of many of these discussions is an 
appreciation that the dialogue initiated cannot remain at single school level and must take place across networks and systems that encompass areas, regions and potentially nations $[27,30]$.

This view of the centrality of networks to effective teaching and learning is reinforced by recent work carried out by the OECD reflecting on the challenges posed by Covid-19 to education systems at a global level. Gouëdard, Pont, Viennet [28] highlight the importance of existing networks for schools seeking to transition to novel teaching and learning environments. They point out that schools who were part of existing networks have the possibility of leveraging this involvement in a manner that might "build on these networks and pool resources such as study plans to focus on what matters the most: maintaining contact with students and the school community and considering innovative ways forward" [28, p. 12]. This recognition is important as it suggests an awareness of the need to explore ways to expand on existing networks in practical ways to enable schools deliver core activities. What is perhaps missing from this is an appreciation of the potentially transformative nature of these networks to the core activities of schools and an acknowledgement of the manner in which networking can facilitate the rethinking of what is central to education across the continuum of provision [31]. In a connected paper we will explore how the development of the DCU Shared Professional Learning Network (DCUSPLN) facilitated such a process in Northern Ireland, emerged and developed over the course of the past decade.

\section{Conclusion}

The nature, role and development of networking has been one of the key areas of innovation in the theory of organisational development in recent decades. There is an increasing awareness that it may offer a new model for organisational improvement across a range of disciplines. Within education there has been a growing awareness of the potential offered by networks in a rapidly changing social and disciplinary context. The capacity of school communities to cooperate in formal and informal clusters has become an essential part of many successful educational systems. In practical terms such cooperation has led to the pooling of expertise across a range of fields as well as providing opportunities to initiate savings in areas such as procurement and staffing. There is also an increasing awareness of the potential of networks to shape quality assurance structures and to improve key outcome indicators through the development of internally coherent support structures and pools of expertise that allow clusters of school communities support each others activities in the linked fields of teaching and learning. The value of networks has been further highlighted in recent months as school communities around the world have been forced to recalibrate and reconceptualise in the face of an unprecedented global pandemic. This emerging reality has the potential to profoundly alter how we think of schools and to challenge us to conceptualise the barriers between schools, between schools and communities and between communities and other stakeholding groups as being permeable rather than closed.

\section{References}

1. R.S. Burt, M. Kilduff, S. Tasselli, Annual Review of Psychology, 64, 527-547 (2013). https://doi.org/10.1146/annurev-psych-113011-143828

2. N. Hertting, E. Vedung, Evaluation, 18(1), 27-46 (2012). https://doi.org/10.1177/1356389011431021

3. C. Chapman, M. Hadfield, Educational Research 52(3), 309-323 (2010). https://doi.org/10.1080/00131881.2010.504066 
4. C. Azorin, School Leadership and Management, 40(2-3), 105-110 (2020). https://doi.org/10.1080/13632434.2020.1745396

5. K.G. Provan, P. Kenis, Journal of Public Administration Research and Theory, 18(2), 229-252 (2008). https://doi.org/10.1093/jopart/mum015

6. N.M. Moolenaar, Ties with potential: Nature, antecedents, and consequences of social networks in school teams, PhD Thesis (University of Amsterdam, Amsterdam, 2010). https://hdl.handle.net/11245/1.374804

7. C. Chapman, H. Chestnutt, N. Friel, S. Hall, K. Lowden, Journal of Professional Capital and Community, 1(3), 178-197 (2016). https://doi.org/10.1108/JPCC-03-20160007

8. C. Chapman, Journal of Educational Administration, 57, 554-570 (2019). https://doi.org/10.1108/JEA-05-2015-0038

9. A.J. Daly, K.S. Finnigan, J Educ Change, 11(2), 111-138 (2010). https://doi.org/10.1007/s10833-009-9102-5

10. L. Earl, S. Katz, School Leadership \& Management, 27(3), 239-258 (2007). https://doi.org/10.1080/13632430701379503

11. S. Rincón-Gallardo, M. Fullan, Journal of Professional Capital and Community, 1(1), 5-22 (2016). https://doi.org/10.1108/JPCC-09-2015-0007

12. D. Muijs, M. West, M. Ainscow, School Effectiveness and School Improvement, 21(1), 5-26 (2010). https://doi.org/10.1080/09243450903569692

13. J. Diaz-Gibson, M. Civis-Zaragoza, J. Guàrdia-Olmos, School Leadership \& Management, 34(2), 179-200 (2014). https://doi.org/10.1080/13632434.2013.856296

14. C.M. Azorin, D. Muijis, Educational Research, 59(3), 273-296 (2017). https://doi.org/10.1080/00131881.2017.1341817

15. C. Hands, School Effectiveness and School Improvement, 21(2), 189-207 (2010). https://doi.org/10.1080/09243450903553993

16. R. Prenger, C.L. Poortman, A. Handelzalts, Journal of Teacher Education, 70(5), 441452 (2018). https://doi.org/10.1177/0022487117753574

17. D. Morgan, B. Cook, New Public Governance. A Regime-Centered Perspective (Routledge, New York, 2015). https://doi.org/10.4324/9781315702100

18. F.J.G. Janssens, M.C.M. Ehren, Evaluation and Programme Planning, 56, 88-98 (2016). https://doi.org/10.1016/j.evalprogplan.2016.03.012

19. J. Diaz-Gibson, M.C. Zaragoza, A.J. Daly, J.L. Mayayo, J.R. Romani, Educational Management Administration \& Leadership, 45(6), 1040-1059 (2017). https://doi.org/10.1177/1741143216628532

20. A. Gonzalez, M. Pino, L. Ahumada, Transistar desde el mejoramiento escolar al mejormiento sistémico: Opportunidades y desafios de las redes escolares en Chile [Moving from school improvement to systemic improvement: Opportunities and challenges of school networks in Chile] (Centro de Liderazgo para la Mejora Escolar, Chile, 2017)

21. A. Hargreaves, M. Fullan, Professional Capital: Transforming teaching in every school (Teachers College Press, New York, 2012)

22. P. Sammons, T. Mujtaba, L. Earl, Q. Gu, School Leadership and Management, 27(3), 218-238 (2007). https://doi.org/10.1080/13632430701379412 
23. Ch. Harrison, Leadership Theory and Research. A Critical Approach to New and Existing Paradigms (Palgrave Macmillan, London, 2018). https://doi.org/10.1007/9783-319-68672-1

24. J. Spillane, A. Harris, M. Jones, British Educational Research Journal, 41(61), 10681085 (2015). https://doi.org/10.1002/berj.3166

25. A. Harris, Distributed Leadership Matters: Perspectives, Practicalities, and Potential (Corwin Press, Thousand Oaks, California, 2013)

26. A. Harris, J. De Flaminis, Management in Education, 30(4), 141-146 (2016). https://doi.org/10.1177/0892020616656734

27. C. Azorin, A. Harris, M. Jones, School Leadership and Management, 40(2-3), 111-127 (2020). https://doi.org/10.1080/13632434.2019.1647418

28. P. Gouëdard, B. Beatriz Pont, R. Viennet, OECD, 12, 224 (2020)

29. M. Brown, G. McNamara, S. O’Brien, C. Skerritt, J. O’Hara, J. Faddar, S. Cinkir, J. Vanhoof, M. Figueiredo, G. Kurum, Improving Schools, 23(1), 85-102 (2020). https://doi.org/10.1177/1365480219895167

30. A. Harris, Journal of Professional Capital and Community, 5(3/4), 321-326 (2020). https://doi.org/10.1108/JPCC-06-2020-0045

31. J. O'Hara, M. Brown, G. McNamara, P. Shevlin, Revista De Investigación Educativa, 38(1), 33-52 (2019). https://doi.org/10.6018/rie.397201 